\title{
Long-term changes in landings of small pelagic fish in the eastern Adriatic - possible influence of climate oscillations over the Northern Hemisphere
}

\author{
Branka Grbec*, Jakov Dulčić, Mira Morović \\ Institute of Oceanography and Fisheries, PO Box 500, 21000 Split, Croatia
}

\begin{abstract}
In order to establish the connection between the hydroclimate variables and pelagic species, year-to-year fluctuations of small pelagic fish landings in the eastern Adriatic coast were compared to climatic fluctuations over the Northern Hemisphere and to salinity fluctuations in the Adriatic. Using this approach, basic climatic oscillations were determined for both hydroclimate and biological data. The main climate oscillation period was approximately $80 \mathrm{yr}$ and an interrelation between climatic fluctuations over the Northern Hemisphere and small pelagic fish landing data was found. The results suggest a linkage between the advection of Levantine Intermediate Water, which is controlled by the pressure distribution over the wider area, and fish abundance in the Adriatic Sea.
\end{abstract}

KEY WORDS: Adriatic Sea $\cdot$ Climatic oscillations $\cdot$ NAO index $\cdot$ Pressure difference $\cdot$ Small pelagic fish landing data

Resale or republication not permitted without written consent of the publisher

\section{INTRODUCTION}

Previous research in the Adriatic has shown that the inflow of Mediterranean water into the Adriatic causes increased productivity in the oligotrophic Adriatic waters (Buljan 1957, Buljan \& Zore-Armanda 1976). Different biological phenomena such as production fluctuations (Pucher-Petković 1970), changes in phytoplankton species composition (Pucher-Petković et al. 1971), higher biomass and a changed zooplankton community composition (Vučetić 1970) were all observed and related to the stronger inflow from the Mediterranean into the Adriatic. Also, different aspects of interactions between thermohaline properties and phytoplankton and fisheries were recognised in many papers (Županović 1968, Škrivanić \& Zavodnik 1973, Regner \& Gačić 1974, Pucher-Petković et al.

*E-mail: grbec@izor.hr
1987, Regner et al. 1987, 1988, Marasović et al. 1988, Vučetić \& Alegria-Hernández 1988). Studies of longterm changes should take into account eutrophication; however, irrespective of the significantly advanced eutrophication in the Northern Adriatic and in Adriatic coastal waters, recent research has pointed to the fact that climatic fluctuations are still crucial for the Adriatic ecosystem dynamics (Marasović et al. 1995).

Impacts of climatic fluctuations are observed from the salinity of the intermediate layer in the eastern middle Adriatic. Namely, through the Otranto Strait, the Levantine Intermediate Water (LIW), which is one of the saltiest waters (>39 psu) (Morcos 1972, Tzipperman \& Malanotte-Rizzoli 1991), enters into the Adriatic (Buljan \& Zore-Armanda 1976). The inflows of the Mediterranean waters into the Adriatic differs from year to year, under the influence of climatic oscillation over an area larger than the Mediterranean. This inflow seems to be controlled by a horizontal pressure difference between the northern and southern Adriatic 
(Zore-Armanda 1972, Grbec 1998), as a part of the large-scale (from Atlantic to Europe) low- and highpressure centre distribution (from the Icelandic cyclone to the Siberian anticyclone) (Zore-Armanda 1969, 1972). It seems that more northeastward-located cyclones increase the zonal pressure difference, which enhances saltier water advection from the Mediterranean into the Adriatic (Grbec et al. 1998). Largescale pressure distributions are related to local environmental conditions; however, the influence of distant permanent pressure centres may not always be direct. Although the NAO (North Atlantic Oscillation) index is found to be important for the atmospheric circulation in the north Atlantic and Mediterranean, all the consequences of its influence are not currently clear.

Wind is a direct consequence of horizontal pressure distribution, and the salinity changes in the intermediate layer are the consequence of wind-induced advection. Recently, the pressure distribution over a wider area, from the Atlantic to the southeast Mediterranean, has been analysed and was found to be responsible for the changes in LIW inflow intensity. However, these changes are a part of the NAO, a primary climatic factor governing hemispheric-scale fluctuations, centred over the Atlantic (Rogers 1984, Jones et al. 1987, Marshall et al. 1997).

This paper seeks to demonstrate the relation between the climatic changes over an area larger than the Adriatic and the small pelagic fish stocks in the Adriatic, via the meso-scale atmospheric pressure fluctuation, which influences both long-term salinity changes and pelagic fish landings.

\section{DATA}

\subsection{Pelagic fish time-series}

The fish landing data used in the analysis correspond to the fish caught in the coastal and open seas of the east Adriatic coast. The catchment area covers the entire fishing area of the east Adriatic coast. Monthly catches (i.e. landings) were recorded at the major pelagic fish ports along the Adriatic coast, such as Izola, Rovinj, Pula, Rijeka, Zadar, Sali, Split, Postira and Komiža, and all the catch data were sent to the periodical 'Morsko ribarstvo' (1947-1995). The main goal of this article is to connect climatic fluctuations to fish-catch fluctuations; therefore, relative changes of the fish-landing data were considered sufficient for the comparison. This statement is supported by the findings of correspondence between interannual changes of the total sardine catches at major and minor ports in Italy and at ports in the former Yugoslavia, which all showed the same temporal pattern (Santojanni et al.
2001). Climate dependence of a fish population is usually derived from biomass data; however, in absence of these data, landing data were taken as a first approximation.

Four species of pelagic fishes were analysed. The long-term series of annual sardine Sardina pilchardus, Walbaum 1792 landing data, from 1873-1997, were used in the analysis. Data from 1873-1945 were taken from Županović (1968), and data from 1946-1997 from the statistical data given in 'Morsko ribarstvo' (1947-1995) and 'Statistički ljetopis' (1995-1998). The long-term series of data for Engraulis encrasicolus (Linnaeus 1758), Sprattus sprattus (Linnaeus 1758) and Scomber scombrus (Linnaeus 1758) annual catches from 1946-1998 were used from the same sources. No estimate of catch per unit effort was made, since it could not be calculated for 1873-1960.

The fish catch does not depend exclusively on environmental conditions in the fishing areas and on fluctuations of the stock, but also on changes of fishing technique, fishing effort, and a number of economic and social factors. The catch of all the mentioned species along the east Adriatic coast reflects these influences, and the time-series may be divided into 6 periods. The first period, from 1873 up to the beginning of the 20th century, is characterised by the use of primitive gear and fishing techniques, which had not changed since the 15th century. During that period, species were caught mostly in the coastal zone. The second phase began with the introduction of acetylene lamps, and lasted until 1935. The third period began with the use of purse seine nets primarily in the sardine fishery and lasted until 1945. The fourth phase is characterised by the rapid increase in the number of new purse seines; the fishing of species spread rapidly towards the open sea, but was still frequently performed in the coastal areas. The fifth phase began in 1960, when echo-sounders were installed on ships and fisheries occurred mostly in the open sea. This phase lasted until 1979, when the last phase began with the introduction of pelagic trawlers into the fishing fleet.

It seems that during the first period there was no substantial change in either fishing technique or fishing effort and that fluctuations of the catch reflected natural fluctuations of the populations only. The same statement is to some extent also true for the second period.

Since then, lots of changes in fishing techniques and fishing effort have taken place, but there was also a substantial increase, for example, in sardine annual catch; it may therefore be concluded that the sardine stock in the Adriatic was not overfished during any phase of fishing development. It may thus be assumed that a large part of the upward trend, evident since the end of the first half of the 1940s, may be attributed to 
the development of the sardine fishery, and that signals of natural fluctuations were mixed with 'noise' caused by the changes in fishing technique and fishing areas. The first signs of a probable anthropogenic influence on the sardine population in the Adriatic, causing an increase in primary productivity, were detected at the beginning of the 1970s, when it was observed that the annual sardine catch increased while fishing effort was on the decrease (AlegriaHernández 1983). A part of the catch increase may be attributed to the use of pelagic trawlers in sardine fisheries, which started to operate in 1979 and which are more efficient than purse seiners; although they make up only about $17 \%$ of the total number of vessels, they effect about $28 \%$ of the sardine catch. The fluctuations derived from sardine assessments in the Adriatic made by Santojanni et al. (2001) do not seem to be strongly influenced by fishing. The same authors noted that between 1981 and 1984 fishing effort increased (76\%) and reached its highest value, as did the biomass; the biomass decrease then began after 1984 .

\subsection{North Atlantic Oscillation and pressure distribution over the Northern Hemisphere}

The NAO index (Hurrell 1995, Jones et al. 1997) for the winter season (December to March average), and for 1873-1995, was obtained from the Climate Research Unit, Norwich, UK (www.cru.uea.ac.uk), computed as a normalised sea-level pressure difference between Gibraltar and Reykjavik (SW Iceland). In this study the NAO index was used to seek the possible linkage between local and global environmental conditions. For the same reason the mean annual pressure data over the Northern Hemisphere were also included in the analysis. The mean annual pressure data for 1873-1995, over the area $40^{\circ} \mathrm{W}-30^{\circ} \mathrm{E}$, $30-65^{\circ} \mathrm{N}$, distributed over grid cells of $5^{\circ}$ latitude by $10^{\circ}$ longitude, were retrieved from the same website.

For the purpose of this paper, based on previous research, the pressure distribution from the north Atlantic to the southeast Mediterranean served to determine the atmospheric mechanism which governs the LIW inflow into the Adriatic. From the whole sealevel pressure field, the horizontal pressure gradient was defined, which was significant for the inflow mechanism. The pressure difference defined by the procedure given in Appendix 1 was correlated to the salinity of the intermediate layer of the middle Adriatic, in order to show the connection between the processes in the atmosphere and in the sea. Although the LIW inflow in the Adriatic is present throughout the year, it is most pronounced in the winter season. Since the fish landing data were available only on an annual scale, pressure differences were calculated as annual average values for each year in 1873-1995.

\subsection{Salinity time-series}

According to an earlier investigation (Grbec \& Morović 1997), 2 different thermohaline layers can be recognised in the middle Adriatic: the surface (down to $20 \mathrm{~m}$ ) and the intermediate (from 20 to $100 \mathrm{~m}$ ). The surface layer is under a strong atmospheric influence, while in the intermediate layer, thermohaline fluctuations can be explained by the horizontal advection of saltier, warmer and more nutrient-rich Mediterranean water. The water in this layer comes mostly from the Mediterranean and is identified as the Modified Levantine Intermediate Water (MLIW) (see Orlić et al. 1992, Zore-Armanda et al. 1999). As an indicator of the intensified Mediterranean inflow, whose various consequences are observed throughout the Adriatic, the annual mean salinity in the intermediate layer of the middle Adriatic, averaged from 50 to $100 \mathrm{~m}$, was used in the analysis. It is in this layer that the highest abundance of the pelagic species is found (Kačić 1980). The data were collected in 1904, 1911-1914 and 1947-1998, during different cruises and at different stations within the area marked in Fig. 1. The salinity fluctuations in the surface layer $(0$ to $50 \mathrm{~m})$ are also presented. All the data were taken from the Marine Environmental Data Bank of the Adriatic Sea (MEDAS) of the Institute of Oceanography and Fisheries, Split, Croatia (Dadić 1996).

\section{METHODS}

The methodology used in this study can be grouped into the following steps:

(1) To establish the variance, all the annual values of fish landing data $\left(a_{i}\right)$ were log-transformed following

$$
A_{i}=\ln \left(a_{i}\right)
$$

It is usual to add the unity constant (the lowest possible catch value) due to the possible occurrence of zeros in the sampling record. In the fish landing data, no zeroes were present, so the constant was not needed.

(2) Long-term trend analysis was performed, determining the basic climatic oscillation (BCO) as a function of both the linear trend and the oscillation, which is described by the harmonic function

$$
y(t)=a_{0}+b_{1} t+a_{1} \sin \left(\frac{2 \pi t}{T}+\psi\right)
$$

where $a_{0}+b_{1} t$ denotes the linear trend and $a_{1}$ and $\psi$ are the amplitude and phase of the first harmonic. The 
best fit of the BCO was determined via numerical calculations using for the initial values the mean (for $a_{0}$ ), the linear trend slope coefficient (for $b_{1}$ ), the standard deviation (for $a_{1}$ ), the largest dominant oscillation

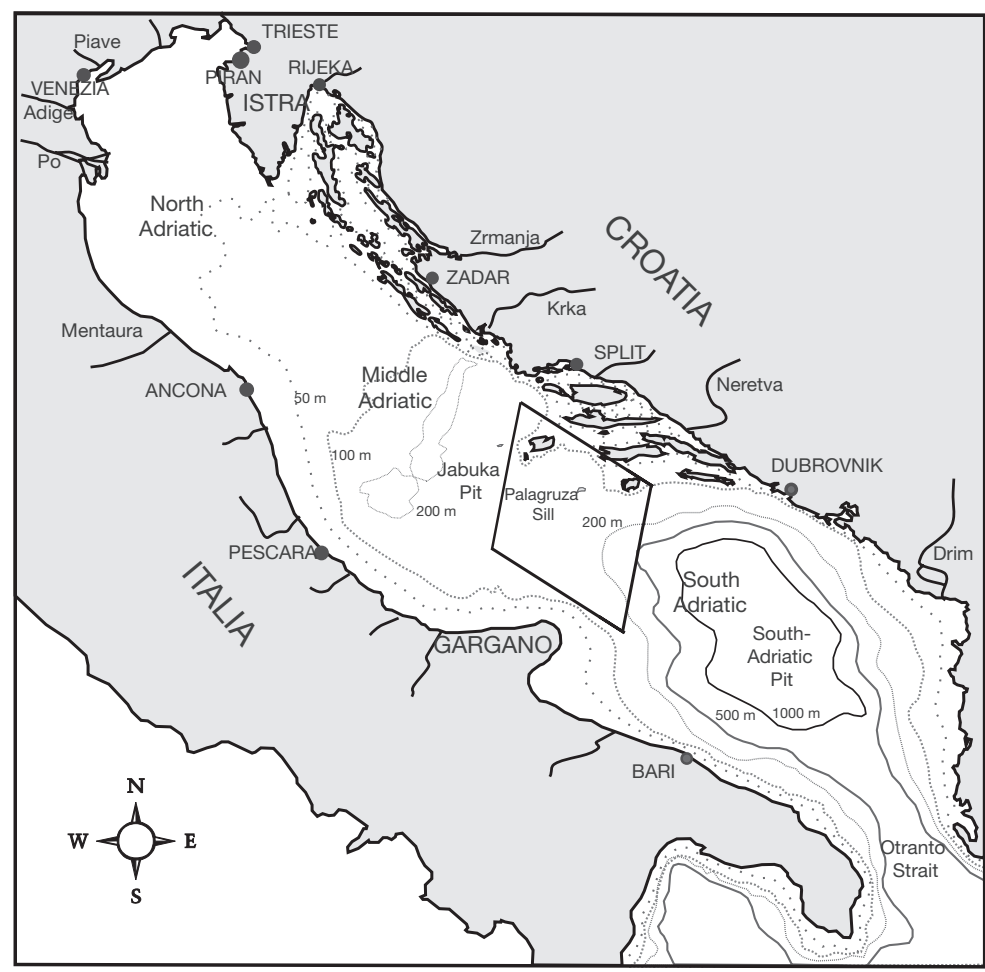

Fig. 1. Adriatic Sea map with marked area in the middle Adriatic where salinity monitoring was performed period $(T)$, and an arbitrary value for $\psi$. BCO was determined for the annual time-series of the small pelagic fish landing data (log-transformed values), salinity, the NAO index and pressure differences.

(3) Relations between the variables were determined using correlation analysis, both for the original and the detrended series (original series minus $\mathrm{BCO}$ ) and for the trends alone (BCO). In order to extract major periods, the detrended series were subjected to crossspectrum analysis. The overall mean and the overall trend are not of interest when one wishes to uncover the periodicity in the series; therefore the mean and the non-linear trend (i.e. BCO) were removed from the series prior to spectral and crossspectrum analysis.

\section{RESULTS}

\subsection{Long-term fluctuations of small pelagic fish landing data}

Year-to-year fish landing data variability for all the analysed species is shown in Fig. 2. Sardine, as the most important commercial species of the eastern Adriatic Sea, has a mean annual catch for 1979-1988 of 30706 t, with a generally increasing trend. This was also observed

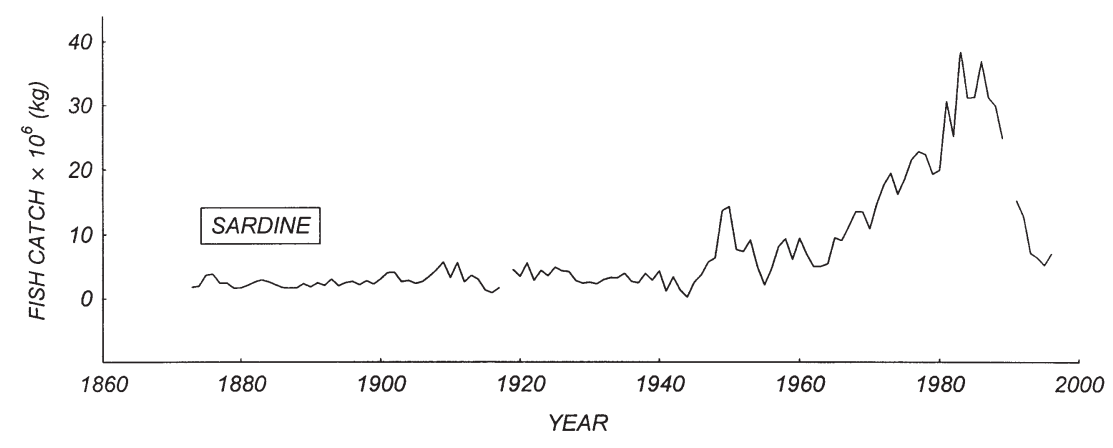

Fig. 2. Interannual time series of the sardine catch, and series of the different pelagic fish species catch (raw data)

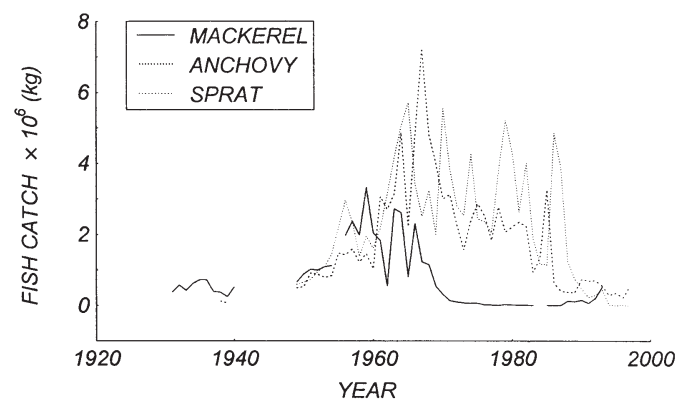



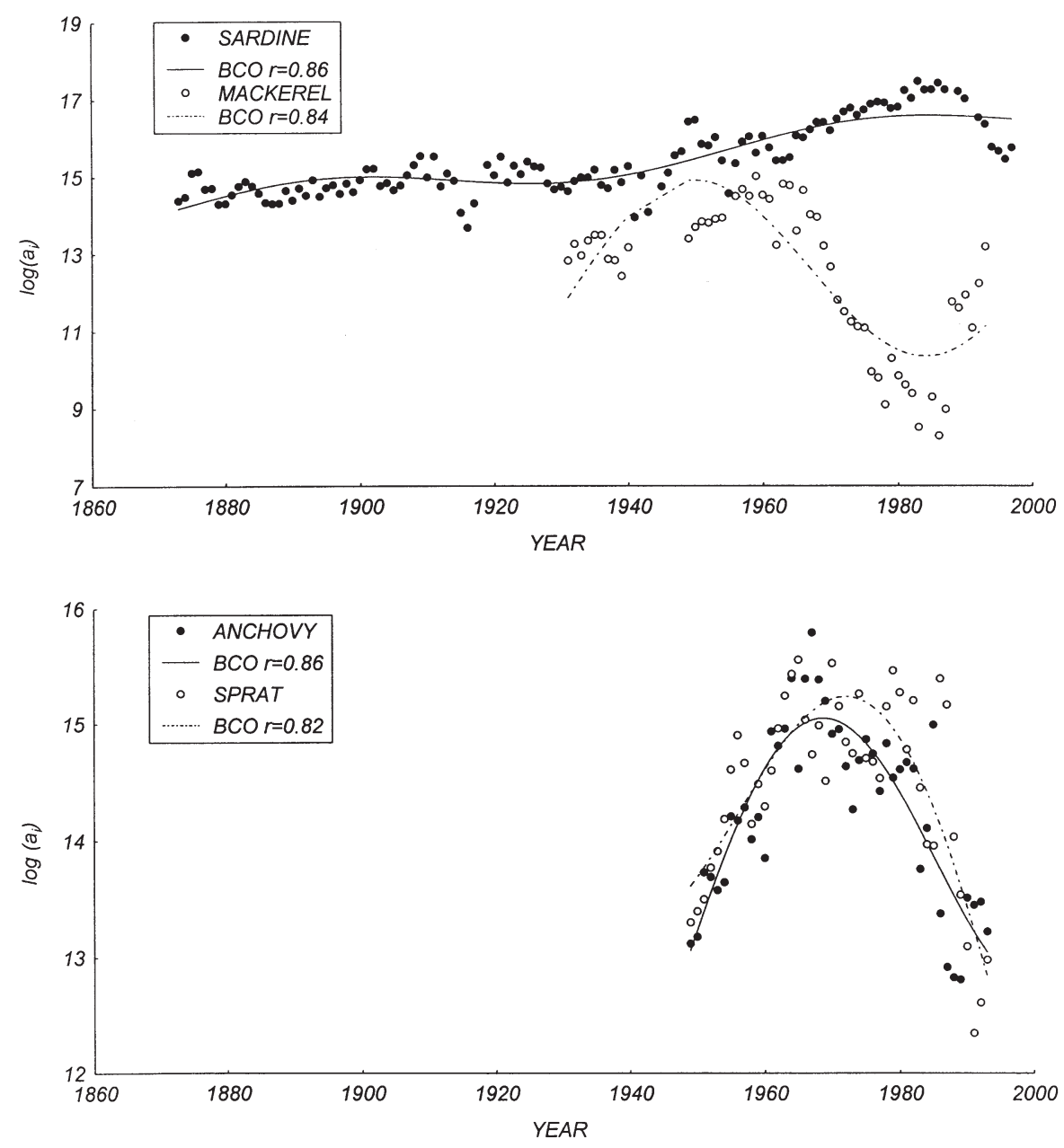

Fig. 3. Basic climatic oscillations (BCO) of the sardine, mackerel, anchovy and sprat catch data, obtained by fitting Eq. (2) to the log-transformed annual values of fish landing data $\left(a_{i}\right)$

in the earlier catch data, with significant short periodic fluctuations, for the eastern Adriatic coast in the period 1950-1990 (Sinovčić 1990). The mean annual catch of anchovy for 1947-1988 was 2111.5 t, with a generally increasing trend; the maximum catch occurred in 1967 (7238 t). Adriatic anchovy catch was very high in the late 1970s, but afterwards it decreased, collapsing in 1987. During this year, with a fishing effort similar to the previous years, catch was only $3700 \mathrm{t}$. It is very likely that the anchovy collapse in 1987 was caused by very low recruitment (Cingolani et al. 1996). The mean annual catch of sprat for 1979-1988 was 3031.5 t with a slightly increasing trend. According to information based on fishermen's reports, there are indications that during the last 2 yr the catch rapidly decreased. There are 2 phases in the trend of mackerel catch. The first phase is characterised by strong fluctuations of relatively high values of catch, especially for 1950-1969.
After that, there was a large drop, with the very low values in 1971-1988; these data show a slight increase. All the analysed series of the small pelagic fish landing data had a significant BCO, which is probably due to the approximately $80 \mathrm{yr}$ period analysed (Fig. 3), although the available periods for anchovy and sprat were relatively short. The best fit curves and the corresponding correlation coefficients for goodness of fit (significant at $\mathrm{p}<0.001$ ) are indicated in the figure.

The correlation coefficients were calculated between the raw data for fish landings, the detrended data series and BCOs (Table 1) for the common period 1949-1993. Significant correlation coefficients were found only between 2 groups: (1) sardine and mackerel and (2) spat and anchovy. Significant negative correlation coefficients were found between BCOs of sardine and mackerel $(r=-0.97 ; p<0.0001)$ when the 2 fluctuated in the opposite phases. 
Table 1. Correlation coefficients (r) between the landings of small pelagic fish for raw data, detrended series, and between the trends alone, for $1949-1993 .{ }^{*}$ Correlation coefficient significant at 0.001 level

\begin{tabular}{|lccc|}
\hline & Sardine & Mackerel & Anchovy \\
\hline Raw data & & & \\
Sardine & 1 & & \\
Mackerel & $-0.89^{*}$ & 1 & \\
Anchovy & -0.07 & 0.12 & 1 \\
Sprat & 0.15 & -0.15 & $0.66^{*}$ \\
Detrended & & & \\
Sardine & 1 & 1 & \\
Mackerel & $-0.65^{*}$ & 0.13 & 1 \\
Anchovy & -0.16 & -0.06 & -0.03 \\
Sprat & 0.19 & & \\
BCO & & & \\
Sardine & 1 & 1 & 1 \\
Mackerel & $-0.97^{*}$ & 0.01 & \\
Anchovy & 0.13 & 0.02 & \\
Sprat & 0.02 & & \\
& & & \\
\hline
\end{tabular}

\subsection{Influence of NAO and pressure oscillations on the fish landing data}

In order to analyse the possible connection between the climatic fluctuations over the Northern Hemisphere and the fish landings, long-term series of small pelagic fish landing data were compared to the NAO index and to the pressure difference between the midnorth Atlantic and Mediterranean (obtained in Appendix 1) (Table 2). Comparing the NAO index to the sardine landing data, no direct correlation was found, although in some periods fluctuations of both parameters correspond (Fig. 4). However, there were signifi-
Table 2. Correlation coefficients (r) between the raw data for landings of small pelagic fish and hydroclimatic variables (NAO: North Atlantic Oscillation). ${ }^{*}$ Correlation coefficient significant at 0.001 level

\begin{tabular}{|lccc|}
\hline & NAO index & Pressure differences & Salinity \\
\hline Sardine & 0.05 & $0.56^{*}$ & $0.43^{*}$ \\
Mackerel & -0.08 & -0.19 & $-0.53^{*}$ \\
Anchovy & $-0.45^{*}$ & 0.04 & 0.12 \\
Sprat & $-0.52^{*}$ & 0.03 & $0.34^{*}$ \\
\hline
\end{tabular}

cant negative correlation coefficients between sprat and anchovy, on the shorter time scale, and winter NAO index. By comparing all the available landing data to salinity variables, significant positive correlation coefficients were found between the raw data for sardine landings and salinity of the intermediate layer (0.43) (Fig. 5) and between residuals of anchovy and residuals of salinity. Mackerel had a significant negative correlation coefficient with salinity. A connection is not evident with the salinity from the surface layer, mainly because salinity fluctuations in this layer are caused by a direct atmospheric influence. The differences between the 2 layers exist every year in the stratified season, but at the annual scale, the differences only exist in some years (Fig. 6). From all the fish parameters, only the sardine data are significantly correlated to the pressure difference (0.56) (Fig. 7).

The detrended fish landing data series, pressure difference, NAO index, and salinity were all subject to the cross-spectrum analysis, in order to discover any correspondence in their fluctuating periods. The analysis revealed a 2 to $3 \mathrm{yr}$ period in all the data sets,

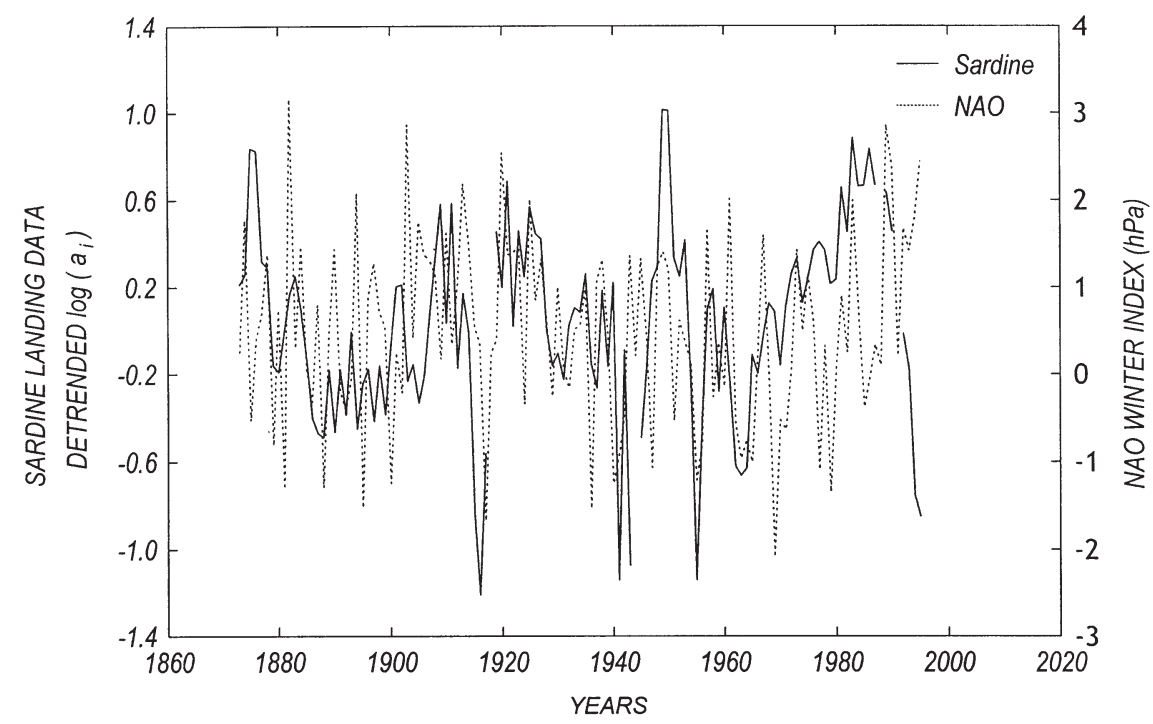

Fig. 4. Annual average of log-transformed sardine catch detrended data compared to the winter NAO index 


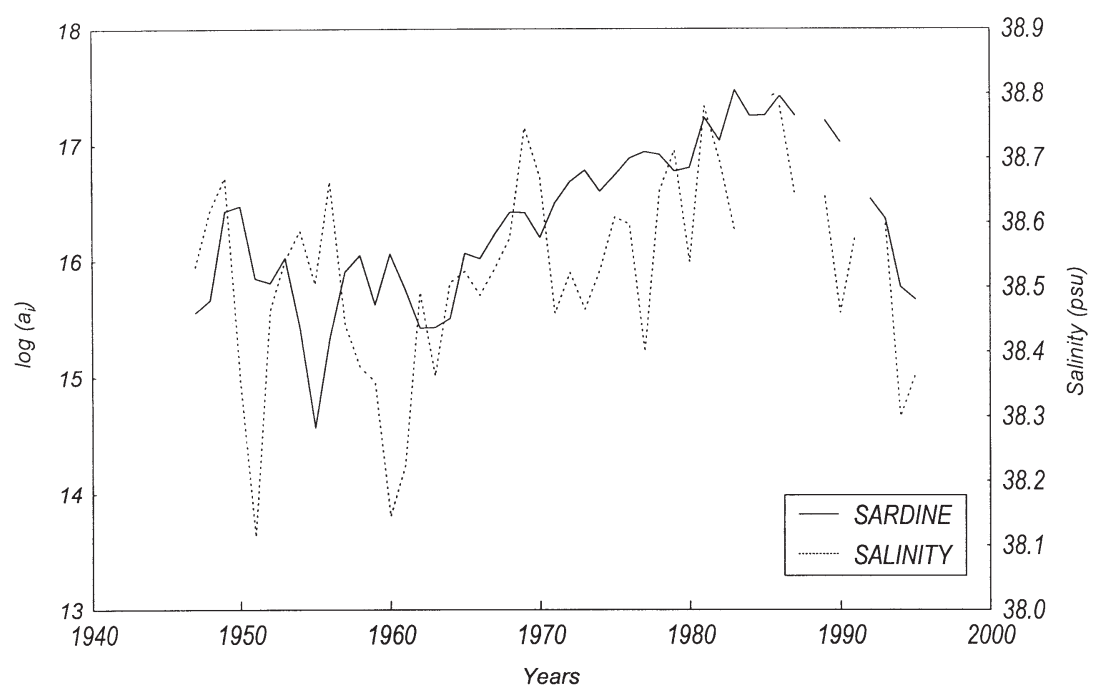

Fig. 5. Interannual changes of intermediate salinity in the middle Adriatic and log-transformed sardine catch

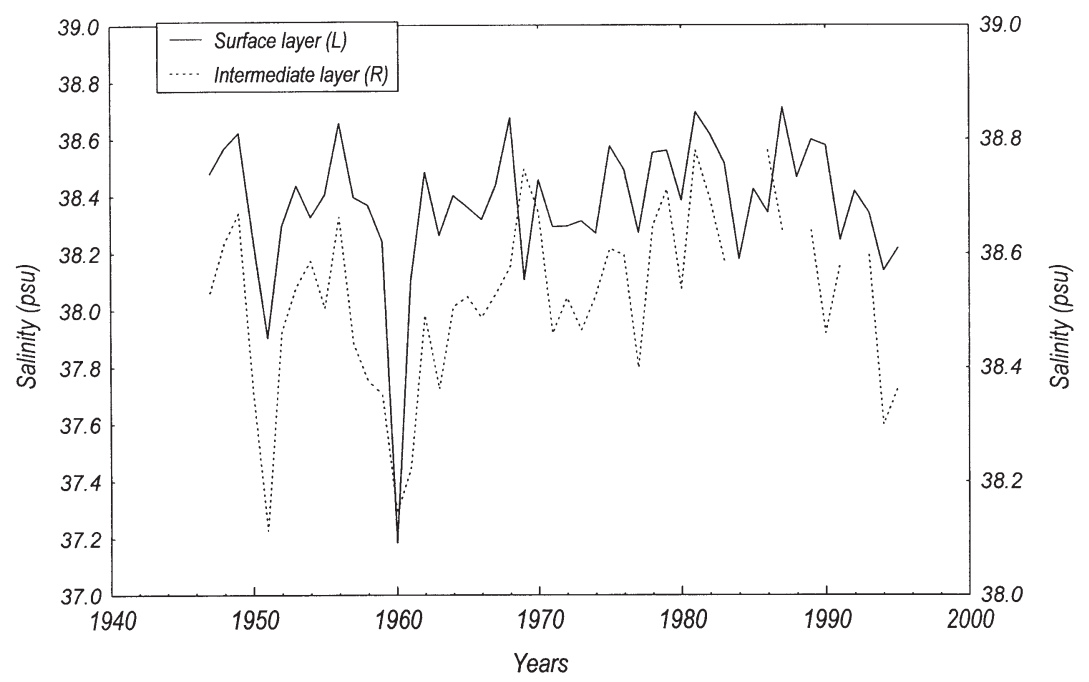

Fig. 6. Interannual changes of salinity in the surface layer (left axis scale) and intermediate layer (right axis scale) in the middle Adriatic

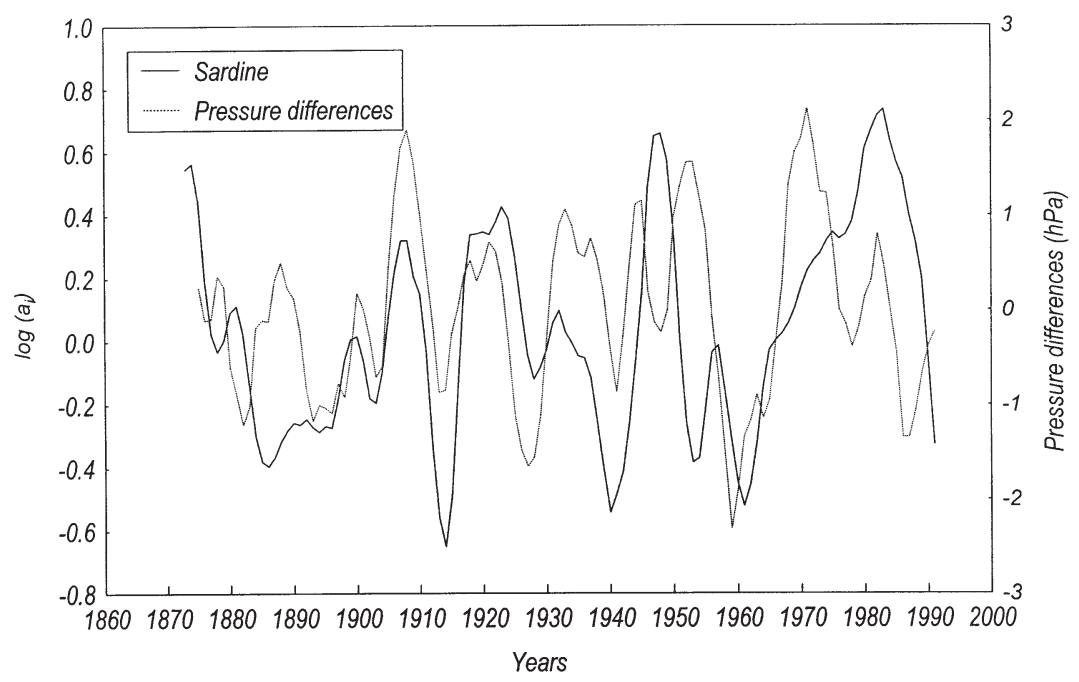

Fig. 7. Interannual variability of sardine catch data and pressure difference between the mid-north Atlantic and southeast Mediterranean. Moving averages are applied to both sets of data 
as well as in pairs of biological and environmental parameters obtained through the cross-spectrum analysis. This fluctuating period is well known from biology to meteorology (Lamb 1972, Fromentin \& Ibanez 1994), and is considered to describe quasi-periodicity. The analysis also showed longer periods of about 7 to 8 yr and 11 to $12.5 \mathrm{yr}$.

\section{DISCUSSION}

The stock dynamics of many fish species - in particular pelagic ones such as anchovy, sardines, herrings, etc. - is thought to be strongly influenced by environmental factors, which determine food availability both in time and space for larvae and juveniles (Shepherd et al. 1984, Bombace 1992, Csirke 1995, Cushing 1996).

Before discussing correlation coefficients between environmental factors and landing data, it is necessary to refer to the hydrographic conditions suitable for each species. Anchovy, mackerel and sprat prefer relatively low salinity (especially sprat); they spawn in the Adriatic between 8.8 and $14.0^{\circ} \mathrm{C}$, and at 36.0 to 37.9 psu (Teskeredžić 1983). The range of temperature conditions for sardine is between 11.0 and $15.0^{\circ} \mathrm{C}$, a maximum number of sardine eggs is found at 12.1 to $13.9^{\circ} \mathrm{C}$ and at a salinity between 38.57 and $38.71 \mathrm{psu}$ (Regner et al. 1987). The sardine prefers the cold season for spawning (October to April, with peaks in December and January) and relatively high salinity, although it is a eurihaline species.

Correlation coefficients in the fish landing data between non-detrended series, detrended series, and within the trends (BCOs) alone (see Table 1) indicate some similarities. On the one hand, there is a strong negative correlation between sardine and mackerel, and on the other a strong positive correlation between anchovy and sprat. The negative correlation between mackerel and sardine may be due to their connection in the food web (see Binet 1996), since mackerel is a predator of the young and adult stages of sardine (Karlovac 1962). Also, since these species prefer somewhat different hydrographic conditions, it is possible that suitable conditions for one of them means that conditions are not favourable for the other. Different responses to salinity are confirmed from the opposite sign of the correlation coefficients between the fish data (sardine and mackerel) and salinity.

The positive correlation between anchovy and sprat could be due to the same hydrographic conditions, which these species prefer. In addition to this, they spawn in different seasons, anchovy in the warm season (May to September, peak in August) and sprat in the cold season (November to February, peak in December-January). Short-term fluctuations, shown from the correlation between detrended series of sardine and mackerel, are highly negatively correlated as well.

During the peaks of the sardine fishery, the catch of other pelagic species behaved differently. Although these changes relate to commercial landings rather than a sampling survey, we may suppose that they reflect species rearrangement in the ecosystem. For example, sardine is partially a phytoplankton feeder and mackerel is strictly a zooplankton feeder and sardine predator. Changes in the fish species abundance can also be viewed as the consequences of a trophic web reorganisation (Binet 1988).

If the wind-stress pulses and relaxation are not matched with the generation time of copepods, primary production will exceed zooplankton feeding capacities, and will favour phytoplankton feeders instead of carnivorous fish. Sardines are plankton feeders and are distinguished from most clupeids by their longer digestive tract, which enables them to digest phytoplankton cells as well as copepods. So, when strong primary-production pulses occur, sardines can thrive and therefore outnumber other fish. During the strong upwelling events, the transfer of primary to secondary production occurs further offshore, so that zooplankton eaters such as mackerel are less abundant over the shelf. Similar alterations of sardine with mackerel are observed in different ecosystems.

The reduction of mackerel stock in the Trieste Bay has already been presented (Orel et al. 1986) to be a result of the modification of the hydrologic cycle used by the species. This, in turn, caused a mismatch between the arrival of the larvae in the nursery zones and the production of suitable food, an event that is considered the principle regulator of the strength of the different year classes of temperate area stocks. A decrease in the stock through this pathway can also occur after a change in the structure of the pelagic ecosystem. This occurs in the sense that the changed environmental conditions could alter, for example, the distribution of the plankton production in the different dimensional compartments, impoverishing the compartment fit for the species in question. Such a situation could occur, for example, because of the passage from a production cycle typical for temperate areas, with 2 well-defined maxima, to one more similar to the typical cycle of subtropical or tropical areas, with production rather uniformly distributed during the year.

The pressure difference (between the mid-north Atlantic and southeast Mediterranean) which reinforces the Mediterranean inflow into the Adriatic can directly and indirectly influence the fish species. It is still to be fully understood which biological consequences could induce changes of this climatic index. $\mathrm{BCO}$ of sardine and raw data for sardine are in high positive correlation with the aforementioned pressure difference. 
From the analyses of the raw data, a significant correlation coefficient between the pressure difference and salinity (inflow indicator) points to the fact that the pressure difference controlled LIW inflow into the Adriatic, and additionally influenced the small pelagic fish stock. In the years with positive pressure difference strong inflow occurred, which is indicated by the salinity increase (>38.5 psu) (Fig. 5). The positive pressure difference implies higher pressure over the mid Atlantic and lower pressure over the southeast Mediterranean. Such a pressure distribution is favourable for LIW formation in the eastern Mediterranean, intensified inflow of more saline LIW into the Adriatic and dense water formation in the northern Adriatic, the phenomena which seem to coincide. The hydroclimate fluctuations in the Adriatic Sea are part of the larger-area atmospheric fluctuations which are described with this pressure difference, in analogy to the way the NAO index describes the climatic fluctuations in the north Atlantic. Years with positive pressure differences, which are years of higher salinity, are also more productive years, considering the phytoplankton productivity. Strong correlation of the species landing data to the pressure difference could also be due to the connection of fish to plankton productivity (Horwood et al. 2000). Bombace (1992) suggested that the fluctuations of small pelagic stocks in the Adriatic Sea may be due to the modifications of the production level in the ecosystem, determined by changing river inputs of nutrients.

The fluctuating period of 11 to $12.5 \mathrm{yr}$ in the fish landing data can be connected to one of the major solar activity cycles, which is observed in many biological processes worldwide. All the analysed series, fish species, salinity and pressure difference have the same fluctuating periods, which indicates a connection to climatic oscillations. Although the NAO index has the same fluctuating period, there was no significant correlation with it except for the anchovy and sprat. Sardine, mackerel and anchovy responded to salinity changes, which are modulated by the climate oscillations in the Adriatic, described by the pressure differences between the mid north Atlantic and southeast Mediterranean.

Questions regarding the recent increase in sardine stock in the northern Adriatic, the disappearance of sprat and the anchovy recovery in recent years remain unanswered. The absence of mackerel during the last few decades is also not fully understood.

The pressure difference, as defined in Appendix 1, represents the changes in the atmosphere at the climatic scale, and its positive correlation to salinity is an indicator of Mediterranean inflow into the Adriatic. Although it is not easy to prove the direct relation of particular meteorological conditions to the fish catch, through this approach the authors believe they have demonstrated the impact of climate variability on the marine ecosystem via the small pelagic fish stock.

It will be necessary to further analyse the links to global climate changes and their atmospheric and oceanographic consequences, especially the increased temperature observed worldwide, which can strongly influence the fish species.

Appendix 1. Pressure field analysis

The mean annual pressure distribution for the Northern Hemisphere within the area $40^{\circ} \mathrm{W}-30^{\circ} \mathrm{E}, 30-65^{\circ} \mathrm{N}$ was analysed for 1873-1995. The intention was to describe pressure changes with a few major components, starting from the 64 pressure variables obtained from particular grid points. This was done by applying principal component analysis (PCA) (Preisendorfer 1982) to the pressure data and extracting the significant components. The first 6 principal components explained $81 \%$ of the entire variability of pressure field (Table A1). Each of the components describes the pressure variability over a certain area within the pressure field. For example, PC1 is related to the variability over the northern Atlantic, since the significant correlation coefficient (0.71) exists between the NAO index and the PC scores of the PC1. The complete field can be described with only these few variables.

From the oscillations of the pressure field, we are only interested in those which somehow can be related to the LIW inflow into the Adriatic. Therefore, the PC scores from all the extracted components were correlated to salinity fluctuations in the intermediate layer, which is the indicator of LIW inflow into the Adriatic. Only 2 correlation coefficients were significant (Table A2); the spatial distributions of the PC loadings are shown in the Fig. A1a. The region of the highest PC loadings of PC4 is the mid north Atlantic; the highest loadings of the PC6 are found in the southeast Mediterranean. It is assumed, therefore, that the pressure difference between these 2 regions, in analogy to the NAO index, defines the oscillation which is on the annual scale, related to salinity fluctuations in the intermediate layer, and thus responsible for the inflow of LIW into the Adriatic (Fig. A1b) .

Table A1. Eigenvalues and explained variance of the first 6 principal components (PCs) extracted from the pressure fields

\begin{tabular}{|ccc|}
\hline PC & Eigenvalues & $\begin{array}{c}\text { Explained } \\
\text { variance (\%) }\end{array}$ \\
\hline 1 & 16.95 & 26.48 \\
2 & 11.77 & 18.39 \\
3 & 9.73 & 15.21 \\
4 & 6.60 & 10.32 \\
5 & 3.86 & 6.04 \\
6 & 2.92 & 4.57 \\
Total explained variance & 80.99 \\
\hline
\end{tabular}


Appendix 1 (continued)

Table A2. Correlation coefficients (r) between the first 6 significant principal component scores and salinity in the intermediary layer of the middle Adriatic. ${ }^{*}$ Correlation coefficient significant at 0.001 level

\begin{tabular}{|cc|}
\hline $\mathrm{r}$ & Salinity \\
\hline PC1 & 0.09 \\
PC2 & -0.09 \\
PC3 & 0.00 \\
PC4 & $0.39^{*}$ \\
PC5 & 0.01 \\
PC6 & $-0.31^{*}$ \\
\hline
\end{tabular}

a

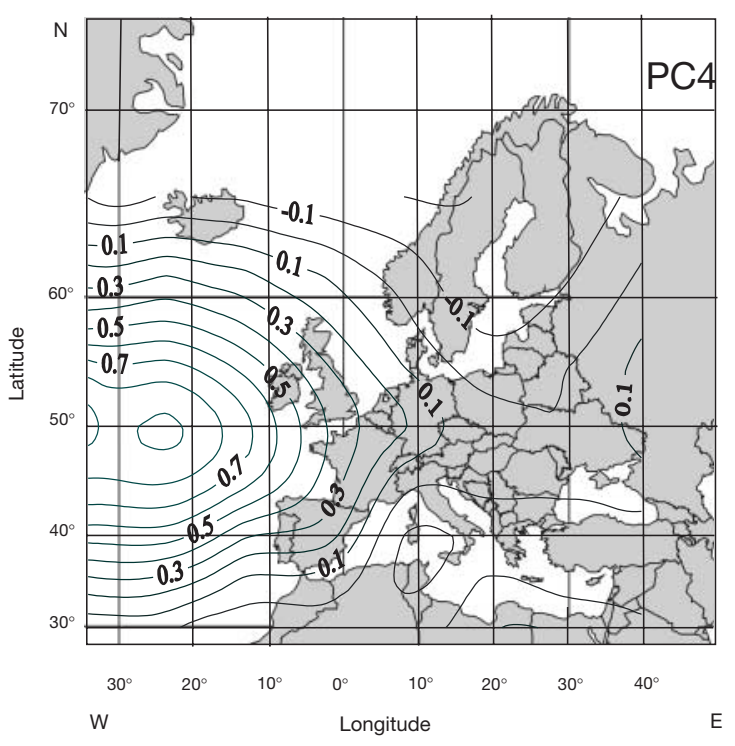

The direct connection between the winds and current systems in the Adriatic and the exchange mechanisms (inflows and outflows) can be better studied at a shorter time-scale than the one used here. It is clear that a very fast barotropic response of the sea to the atmospheric pressure changes exists, which implies that the Adriatic reacts with a stronger outflow to the intensified Mediterranean inflow. Compensation usually takes place in all the layers along the western coast and in the bottom layer. Higher pressure differences imply stronger inflow from the Mediterranean into the Adriatic, but is assured only in some years. A better explanation of this mechanism, that may also include the outflow caused by westerly winds, which produces Ekman volume transport in a southerly direction, or some other mechanisms, will be considered in future studies.

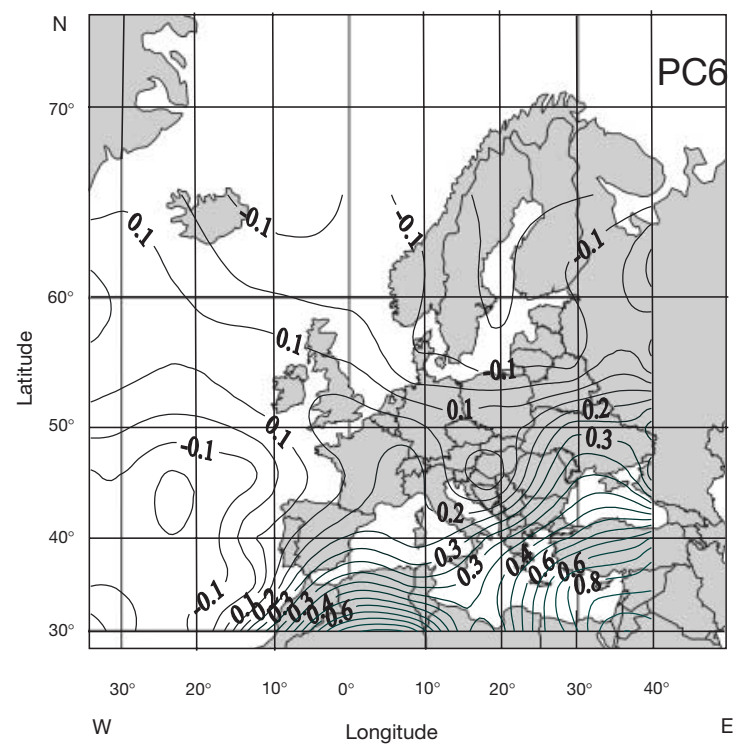

b

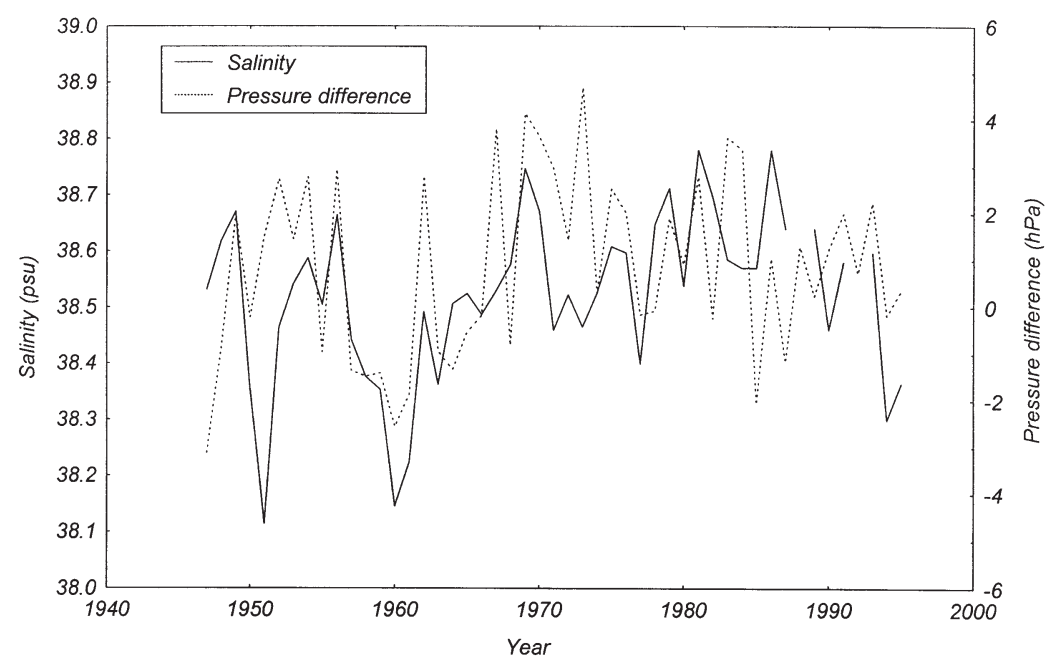

Fig. A1. (a) Spatial patterns of the 2 principal component modes (PC4 and PC6) extracted from the pressure field. (b) The timeseries of pressure differences between mid north Atlantic and southeast Mediterranean and salinity in the intermediate layer of the middle Adriatic 


\section{LITERATURE CITED}

Alegria-Hernández V (1983) Assessment of pelagic fish abundance along the eastern Adriatic coast with special regard to sardine (Sardina pilchardus Walb.) population. Acta Adriat 24(1/2):55-95

Binet D (1988) Role possible d'une intensification des alizes sur le changement des repartition de sardines et sardinelles de long de la cote ouest Africaine. Aquat Living Resour 1:115-132

Binet D (1996) Climate and pelagic fisheries in the Canary and Guinea currents 1964-1993: the role of trade winds and the Southern Oscillation. Oceanol Acta 20:177-190

Bombace G (1992) Fisheries of the Adriatic Sea. In: Colombo G, Ferrari I, Ceccherelli VU, Rossi R (eds) Marine eutrophication and population dynamics. 25th European Marine Biology Symposium. Ferrara, 10-15 September 1990, Olsen \& Olsen, Fredensborg, p 379-389

Buljan M (1957) Fluctuation of temperature in the open Adriatic. Acta Adriat 8(7):1-26

Buljan M, Zore-Armanda M (1976) Oceanographical properties of the Adriatic Sea. Oceanogr Mar Biol Annu Rev 14: $11-98$

Cingolani N, Giannetti G, Arneri E (1996) Anchovy fisheries in the Adriatic Sea. Sci Mar 60(Suppl 2):269-277

Csirke J (1995) Fluctuations in abundance of small and midsize pelagics. Sci Mar 59:481-490

Cushing DH (1996) Towards a science of recruitment in fish populations. In: Kinne O (ed) Excellence in Ecology. Ecology Institute, Oldendorf/Luhe

Dadić V (1996) MEDAS, Mediterranean Environmental Database of the Adriatic Sea. In: Proc ELMAR 38th Int Symp Electronics in Marine, 24-26 June 1996, p 65-60

Fromentin JM, Ibanez F (1994) Year-to year changes in meteorological features of the French coast area during the last half-century: examples of two biological responses. Oceanol Acta 17:285-296

Grbec B (1998) Influence of climatic changes on oceanographic properties of the Adriatic Sea. Acta Adriat 38(2):3-29

Grbec B, Morović M (1997) Seasonal thermohaline fluctuations in the middle Adriatic Sea. Nuovo Cim Soc Ital Fis CGeophys Space Phys 20(4):561-576

Grbec B, Morović M, Zore-Armanda M (1998) Some new observations on the long-term salinity changes in the Adriatic Sea. Acta Adriat 39 (1):3-12

Horwood J, Cushing D, Wyatt T (2000) Planktonic determination of variability and sustainability of fisheries. J Plankton Res 22(7):1419-1422

Hurrell JW (1995) Decadal trends in the North Atlantic Oscillation and relationships to regional temperature and precipitation. Science 269:676-679

Jones PD, Wigley TML, Briffa KR (1987) Monthly mean pressure reconstructions for Europe (1780-1980) and North America (1858-1980). DOE Tech Rep No. Tr037. US Department of Energy, Carbon Dioxide Research Division, Washington, DC

Jones PD, Jónsson T, Wheeler D (1997) Extension to the North Atlantic Oscillation using early instrumental pressure observations from Gibraltar and south-west Iceland. Int J Climatol 17:1433-1450

Kačić I (1980) Pelagic fish in the Adriatic: distribution and stock assessment. FAO Fish Rep 239:21-31

Karlovac J (1962) Investigation of the digestive tract of planktonic stadium of sardine (Sardina pilchardus Walb.) in the open waters of the Adriatic Sea. Izviješća rib -biol- eksp 'Hvar' 1948-1949, Vol IV(4D), Split (in Croatian)

Lamb HH (1972) Climate, present, past and future, Vol 1.
Methuen, London

Marasović I, Pucher-Petković T, Alegria-Hernández V (1988) Phytoplankton productivity of the Adriatic Sea in relation to pelagic fisheries. Bilješke-Notes 72:1-8

Marasović I, Grbec B, Morović M (1995) Long-term production changes in the Adriatic. Neth J Sea Res 34(4):267-273

Marshall J, Kushnir Y, Battisti D, Chang P, Hurrell J, McCartney M, Visbeck M (1997) A 'white paper' on Atlantic climate variability. Available at http://www.cru.uea.ac.uk

Morcos S (1972) Sources of the Mediterranean intermediate water in the Levantine Sea. In: Gordon AL (ed) Studies in physical oceanography, Vol 2. Gordon \& Breach Science Publishers, New York, p 185-206

Morsko ribarstvo (1947-1995) Poduzeće za unapređenje i razvoj morskog ribarstva d.o.o. Marine Fisheries, Zagreb

Orel G, Vio E, Princi M, Del Piero D, Aleffi F (1986) Stati di anossia dei fondali popolamenti teutonici e pesca. Nova Thalassia 8(Suppl 3):267-280

Orlić M, Gačić M, Laviolette PE (1992) The currents and circulation of the Adriatic Sea. Oceanol Acta 15(2):109-124

Preisendorfer RW (1982) Principal component analysis in meteorology and oceanography. Elsevier, Amsterdam

Pucher-Petković T (1970) Seasonal and interannual fluctuation of primary production in the middle Adriatic. Pomorski zbornik 8:847-856 (in Croatian)

Pucher-Petković T, Zore-Armanda M, Kačić I (1971) Primary and secondary production of the middle Adriatic in relation to climatic factors. Thalassia Jugosl 7(1):301-311

Pucher-Petković T, Marasović I, Vukadin I, Stojanoski L (1987) Time series of productivity parameters indicating eutrophication in the middle Adriatic waters. In: Caddy JF, Savini M (eds) Fifth technical consultation of stock assessment in the Adriatic. GFCM, FAO Fish Rep 394:41-50

Regner S, Gačić M (1974) The fluctuations of sardine catch along the eastern Adriatic coast and solar activity. Acta Adriat 19 (11):1-44

Regner S, Regner D, Marasović I, Kršinić F (1987) Spawning of sardine, Sardina pilchardus (Walb.) in the Adriatic under upwelling conditions. Acta Adriat 1-2:161-198

Regner S, Piccinetti-Manfrin G, Piccinetti C (1988) The spawning of sardine, Sardina pilchardus (Walb.) in the Adriatic as related to the distribution of temperature. FAO Fish Rep 394:127-132

Rogers JC (1984) The association between the North Atlantic Oscillation and the Southern Oscillation in the Northern Hemisphere. Mon Weather Rev 112:1999-2015

Santojanni A, Arneri E, Belardinelli A, Cingolani N, Giannetti G (2001) Fishery and stock assessment of Sardina pilchardus (Walb.) in the Adriatic Sea. Acta Adriat 42(1):151-168

Shepherd JG, Pope J, Cousins RD (1984) Variations in fish stocks and hypotheses concerning their links with climate. Rapp P-V Reun Cons Int Explor Mer 185:255-267

Sinovčić G (1990) Stock size assessment of sardine Sardina Pilchardus (Walb.) in the middle Adriatic. Acta Adriat 32 (2):869-884

Škrivanić A, Zavodnik D (1973) Migration of the sardine, Sardina pilchardus, in relation to hydrographical conditions of the Adriatic Sea. Neth J Sea Res 7:7-18

Statistièki ljetopis (1995-1998) Državni zavod za statistiku republike Hrvatske. Statistical yearbook, Central Bureau of Statistics of the Republic of Croatia, Zagreb

Teskeredžić Z (1983) Spawning of the sprat, Sprattus sprattus (L.) in the Kvarner region and Rijeka Bay. Acta Adriat 24(1/2):13-24

Tzipperman N, Mallanotte-Rizzoli P (1991) The climatological seasonal circulation of the Mediterranean Sea. J Mar Res 49:411-434 
Vučetić T (1970) Zooplankton fluctuations in the middle Adriatic. Pomorski zbornik 8:867-881 (in Croatian)

Vučetić T, Alegria-Hernández V (1988) Trends of annual catches or stock densities of some pelagic fishes in recent 'Pelagia years' in the Adriatic. In: Caddy JF, Savini M (eds) Fifth technical consultation of stock assessment in the Adriatic. GFCM, FAO Fish Rep 394:133-136

Zore-Armanda M (1969) Water exchange between the Adriatic and the eastern Mediterranean. Deep-Sea Res 16:171-178

Editorial responsibility: Gerd Esser,

Gießen, Germany
Zore-Armanda M (1972) Response of the Mediterranean to the oceanographic/meteorological conditions of the northern Atlantic. Rapp Comm Int Mer Médit 21:203-205

Zore-Armanda M, Grbec B, Morović M (1999) Oceanographic properties of the Adriatic Sea-a point of view. Acta Adriat 40:39-54

Županović Š (1968) On the causes of fluctuations in sardine catches along the eastern coast of the Adriatic Sea. Anali Jadranskog Inst 4:401-491 (in Croatian)

Submitted: September 18, 2000; Accepted: October 18, 2001 Proofs received from author(s): February 28, 2002 